\title{
Spatial distribution of lineages of oak powdery mildew fungi in France, using quick molecular detection methods
}

\author{
Amira Mougou-Hamdane ${ }^{1}$, Xavier GIRESSE $^{2}$, Cyril Dutech $^{1}$, Marie-Laure Desprez-Loustau $^{1 *}$ \\ ${ }^{1}$ INRA, UMR1202 BIOGECO, Équipe de Pathologie Forestière, 71 avenue Édouard Bourleaux, 33140 Villenave d'Ornon, France \\ ${ }^{2}$ INRA, UMR1065 Santé Végétale, Équipe Diversité et Adaptation des Populations de Bioagresseurs, 71 avenue Edouard Bourleaux, \\ 33140 Villenave d'Ornon, France
}

(Received 24 February 2009; accepted 25 June 2009)

\author{
Keywords: \\ Erysiphe alphitoides / \\ Erysiphe quercicola / \\ cryptic species / \\ Erysiphales / \\ ITS / \\ biological invasion
}

\begin{abstract}
- Powdery mildew is a major fungal disease of oaks in Europe. Recent studies using internal transcribed spacer (ITS) sequences suggested the presence of four different lineages (putative species). The objective of the study was to investigate the spatial distribution of these lineages/species and, in particular, to test the hypothesis of a spatial differentiation, at various scales: regional (France), altitudinal (a Pyrenean transect) and local (within a forest plot).

- Detection methods for the four ITS types were developed: (1) single strand conformation polymorphism analysis (SSCP); (2) PCR amplifications, for which specific primers were designed. SSCP proved to be efficient for the detection of Erysiphe alphitoides and E. quercicola types. In contrast, the rarer ITS types corresponding to E. hypophylla and Phyllactinia guttata (sensu lato) were only detected by specific amplification.

- The study confirmed the strong predominance of the ITS sequence associated with E. alphitoides at all spatial scales (with a frequency higher than $80 \%$ ). Isolates presumably belonging to E. quercicola (i.e. with same ITS type), a recently described species not yet recorded in Europe, were also found in all French regions at a significant frequency (15\% at national level).

- No pattern of spatial differentiation between the putative species could be demonstrated: E. alphitoides was often found in association with different ITS types in the same region, the same tree, and even in the same lesion.
\end{abstract}

Résumé - Distribution spatiale de lignées d'oïdium des chênes en France analysée à l'aide d'outils rapides de caractérisation moléculaire.

- L'oïdium est l'une des maladies fongiques les plus importantes sur chênes en Europe. Des études récentes basées sur l'internal transcribed spacer (ITS) ont suggéré l'implication de quatre lignées (espèces putatives) différentes. L'objectif de l'étude était de caractériser la distribution spatiale de ces lignées/espèces et en particulier de tester l'hypothèse d'une différenciation spatiale à plusieurs échelles : régionale (France), altitudinale (transect pyrénéen) et locale (au sein d'une parcelle forestière).

- Des méthodes de détection des quatre types d'ITS ont été développées : (1) analyse SCCP ; (2) amplification par PCR de l'ITS par des amorces spécifiques. La SSCP a permis de détecter facilement les ITS correspondant à E. alphitoides et E. quercicola. Par contre, les ITS plus rares correspondant à E. hypophylla et Phyllactinia guttata (sensu lato) n'ont été détectés que par amplification spécifique. - L'étude a confirmé la forte prédominance (avec une fréquence supérieure à $80 \%$ ) de la séquence d'ITS associée à E. alphitoides. Les isolats présentant la même séquence d'ITS qu'E. quercicola, espèce récemment décrite et encore non mentionnée en Europe, ont également été retrouvés dans toutes les régions françaises à une fréquence importante (15\% en moyenne pour l'échantillonnage national).

- Aucune différenciation spatiale entre les espèces putatives n'a pu être mise en évidence : E. alphitoides a souvent été détectée en association avec des isolats de différents types d'ITS dans la même région, le même arbre, voire la même lésion.

\footnotetext{
*Corresponding author: loustau@bordeaux.inra.fr
} 


\section{INTRODUCTION}

Powdery mildew is among the most important diseases of oak in European forests (Butin, 1995). The disease appeared suddenly and propagated to almost all Europe in the early 20th century. It was particularly severe on Quercus robur and foresters were afraid that powdery mildew could decimate indigenous oaks (see Mougou et al. 2008, for history of the disease and early references). The sudden apparition (i.e. disease records were absent prior 1907), as well as the spread of the disease and its severity on oaks, supported the exotic invader hypothesis (Raymond, 1927). Although some mycologists suggested the introduction of an American species, a new species, Microsphaera alphitoides Griffon and Maubl. (current name: Erysiphe alphitoides (Griffon and Maubl.) U. Braun and S. Takam.) was described by Griffon and Maublanc (1912) on the basis of morphological differences with previously described oak powdery mildew species.

We recently revisited the question of the identity of the fungi that cause oak powdery mildew in Europe, especially France, by using analyses of nuclear ribosomal internal transcribed spacers (ITS) sequences (Mougou et al., 2008). The analyses of ribosomal DNA have supplemented the classical morphological criteria used in fungal taxonomy and helped to establish new fungal phylogenies (White et al., 1990), including for Erysiphales (Saenz and Taylor 1999, Takamatsu, 2004). Specifically, based on the finding that polymorphisms found in the ITS generally differentiate between species (White et al., 1990), this region has been assigned a primary role in molecular identification of fungal species. This role is especially valued with the barcoding approach (Hebert et al., 2003), although no single unifying threshold in sequence divergence could be defined for species delimitation among fungi (Nilsson et al., 2008).

Our previous work confirmed the presence of three species already reported in Europe as causal agents of powdery mildew on oaks: $E$. alphitoides and, far less frequently, $E$. hypophylla (Nevod.) U. Braun \& Cunningt. and Phyllactinia guttata (Wallr.) Lév. (sensu lato, including $P$. roboris (Gachet) S. Blumer), on the basis of their ITS signature (Mougou et al., 2008). An unexpected additional finding was the detection of a fourth ITS type, which exactly matched the sequence of a new species recently described on Asian oaks, Erysiphe quercicola S. Takam. \& U. Braun and not yet recorded in Europe (Limkaisang et al., 2005; 2006; Takamatsu et al., 2006). The occurrence of several species, or at least genetically differentiated groups, could have important epidemiological implications, with the severity of the disease possibly linked to the behaviour of each group. For example, recent studies with grapevine powdery mildew confirmed the presence of two genetically differenciated biotypes which could lead to two different forms of the disease (Delye and Corio-Costet, 1998; Montarry et al., 2008). The different frequencies of the two biotypes during epidemic progress in a season is consistent with putative different ecological requirements between the two biotypes (Montarry et al., 2009). There is mounting evidence of the existence of cryptic species or genetically differentiated groups within fungi (Taylor et al., 2006), especially pathogenic fungal species (e.g. Crous et al., 2004; Fournier and Giraud 2008). In some cases, cryptic species were shown to exhibit different geographical ranges (Taylor et al., 2006). In other cases, such as grapevine pathogens, the coexistence of competing groups of organisms sharing common food needs raises the question of niche differentiation (Montarry et al., 2008; 2009). Similar questions need to be adressed on oak powdery mildew, but a prerequisite is an accurate description of the spatial distribution of the four lineages (putative species) in European forests.

The aim of the present study was to investigate the spatial distribution of the four lineages/species of fungi causing oak powdery mildew in France, and, in particular, to test the hypothesis of a spatial differentiation, at various scales. This required the development of molecular methods for the rapid identification of the four ITS types in large samplings. Single-strand conformational polymorphism analysis (SSCP) was used as an inexpensive, convenient, and sensitive method for determining genetic variation (Orita et al., 1989; Sunnucks et al., 2000). This analysis was completed by specific amplifications developed for the four ITS types.

\section{MATERIAL AND METHODS}

\subsection{Population sampling}

Three samplings performed at various spatial levels were analysed.

A regional sampling covering most of France was performed by the DSF technicians (Département de la Santé des Forêts - Ministry of Agriculture, France) from June to October 2007 (with the majority of samples in July), on the $16 \mathrm{~km} \times 16 \mathrm{~km}$ grid of the European International Co-operative Programme Forests network (http://www.icpforests.org/), in oaks-containing plots. This gave 108 plots in different areas of the country. The sampling was mainly focused on $Q$. robur which is the most widely distributed oak species and one of the most susceptible species to powdery mildew (Ayres, 1976). However, additional samples were taken on other oak species (see below). For each plot, five leaves sampled on five different oak trees were collected, wrapped in paper and sent by postal mail to the laboratory for processing. Leaves with inconspicuous infection or in bad condition were discarded at reception, giving a final number of 470 samples.

The second sampling was achieved on an altitudinal gradient in the western Pyrenees region. Quercus robur seedlings were initially grown from acorns in a greenhouse, until they had 5-10 leaves in a susceptible stage (i.e. soft, not fully expanded, Edwards and Ayres 1982). These seedlings were then placed at five altitudes in the Luz valley (latitude from $42^{\circ} 47^{\prime} \mathrm{N}$ to $43^{\circ} 45^{\prime} \mathrm{N}$; longitude from $00^{\circ} 25^{\prime} \mathrm{W}$ to $00^{\circ} 01^{\prime} \mathrm{E}$ ) in May-June 2006 and 2007 and exposed during ten days allowing powdery mildew infections to take place. Seedlings were then taken back to the laboratory and incubated during ten days in a growth chamber $\left(16 \mathrm{~h}\right.$ light, $26^{\circ} \mathrm{C} / 8 \mathrm{~h}$ dark, $\left.19^{\circ} \mathrm{C}\right)$ to enable sporulation. One white circular spot corresponding to a sporulating lesion was sampled per seedling, resulting in 83 samples in 2006 and 150 in 2007.

The third sampling was achieved in June 2006, within a plot in the state forest of Campet (latitude $44^{\circ} 12^{\prime} 14^{\prime \prime} \mathrm{N}$; longitude $\left.00^{\circ} 10^{\prime} 11^{\prime \prime} \mathrm{W}\right)$. Samples were taken from $16 Q$. robur and one 


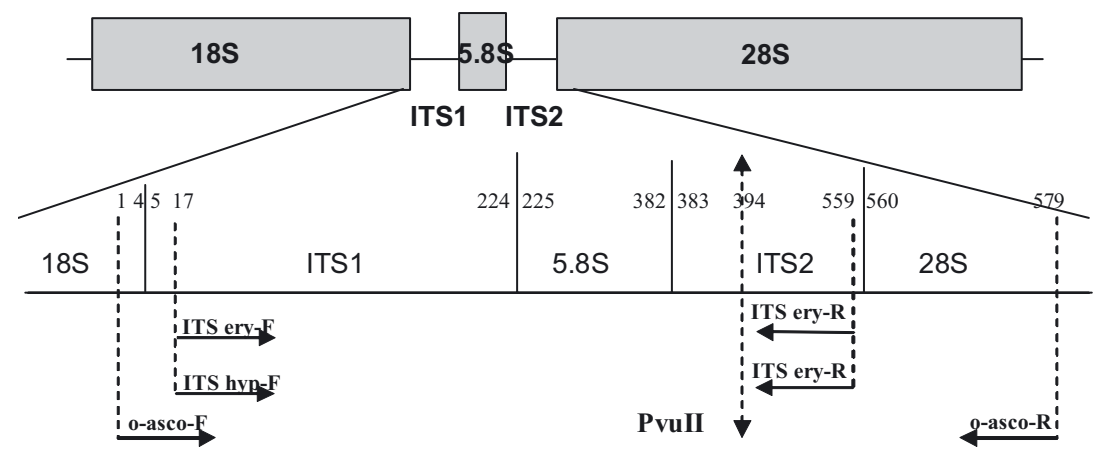

E. alphitoides: $\mathrm{CAG}^{\wedge} \mathrm{CTG}$

E. quercicola: CAGTTA

Figure 1. Locations of PCR primers and of PvuII restriction site in the ITS sequence for Erysiphe species.

Table I. Sequences of primer pairs used for specific amplifications.

\begin{tabular}{ll}
\hline Species & Sequence \\
\hline E. alphitoides + E. quercicola & $\left\{\begin{array}{l}\text { ITS-ery F 5'- CTCAGTCGTGGCATCTGCT-3' } \\
\text { ITS-ery R 5' - ATGTGACTGGAGCAAGTGG-3' }\end{array}\right.$ \\
E. hypophylla & $\left\{\begin{array}{l}\text { ITS-hyp F 5'-CTCAGTCGTGGCATCTGCC-3' } \\
\text { ITS-ery R 5' - ATGTGACTGGAGCAAGTGG -3' }\end{array}\right.$ \\
$\begin{array}{l}\text { P. gutatta (Mmbaga } \text { et al., 2004) } \\
\text { PG } 5 \text { 5'-CTGAGCGTGAAGACTCTC-3' } \\
\mathrm{PG}_{2} 5^{\prime} \text {-GGTATCCCTACCTGATTC-3' }\end{array}$ \\
\hline
\end{tabular}

Q. pyrenaica trees, distant from 15 to $500 \mathrm{~m}$ (with 1 to 6 leaves per tree), giving a total of 96 samples.

\subsection{Fungal material}

All the samples consisted of leaves bearing sporulating lesions (mycelium and conidia, i.e. anamorph stage) of oak powdery mildew. Sporulating lesions were mainly observed on the upper side of leaves. When present, sporulating lesions on the lower side were sampled. One leaf fragment of $\sim 0.5 \mathrm{~cm}^{2}$ was cut out with a scalpel in a sporulating lesion in each leaf. These fragments were transferred into $2 \mathrm{~mL}$ microtubes, labelled according to their origins and stored at $-80{ }^{\circ} \mathrm{C}$ before DNA extraction.

\subsection{Detection of oak powdery mildew ITS types}

Fungal DNA was extracted using a slightly modified protocol previously described by Zolan and Pukkila (1986), without grinding of leaf fragments (see Mougou et al., 2008).

For SSCP analysis, the non specific amplification of the ITS region was achieved using the o-asco for/o-asco rev primer pair which had been designed to amplify ascomycota fungi (Heuser and Zimmer, 2002). For each individual reaction, $5-10 \mu \mathrm{L}$ of the PCR product was mixed with $5 \mu \mathrm{L}$ of a solution containing $95 \%$ formamide, $20 \mathrm{mM}$ EDTA, $0.05 \%$ bromophenol blue and $0.05 \%$ xylene cyanol. Sequence polymorphism was revealed by loading $3.5 \mu \mathrm{L}$ of the previous mixture on a $6 \%$ non-denaturing polyacrylamide gel with a migration at $4{ }^{\circ} \mathrm{C}$ at $10 \mathrm{~W}$ overnight. The gel was silver-stained as described by
Benbouza et al. (2006). DNA templates of the different ITS types already sequenced in Mougou et al. (2008) were used as reference samples.

In addition to SSCP, we tried to design oligonucleotide primer pairs for the four ITS types in order to perform specific PCR-based detection. For the Phyllactinia species, the $\mathrm{PG}_{1} / \mathrm{PG}_{2}$ primers already described in the literature (Mmbaga et al., 2004) for the amplification of $P$. guttata from Cornus were used, since we checked from sequence alignments that they could amplify the sequence of Phyllactinia obtained in our previous study (Mougou et al., 2008). For the Erysiphe species, the three ITS sequences corresponding to E. alphitoides, E. hypophylla and E. quercicola were aligned, and the PRIMER 3 software (Rozen and Skaletsky, 2000) was used to design primer sets in the variable regions. Given the different parameters required for the choice of oligonucleotides (e.g. length of the primer, GC content, hybridizing temperature) and the low diversity of sequences, only two primer pairs could be designed: one common to E. alphitoides and $E$. quercicola (ITS-ery F/ITS-ery R), the other for E. hypophylla (ITShyp F/ITS- ery R) (Fig. 1; Tab. I). The two primer pairs only differed by one base (CT vs. $\mathrm{CC}$ at the $3^{\prime}$ end) in the forward primer. Although a $\mathrm{CC}$ dinucleotide at the $3^{\prime}$ end is generally assumed to ensure correct binding specificity (Lowe et al. 1990), sequencing of the amplicon was used to ascertain the results when positive amplification was obtained with E. hypophylla primers. Polymerase chain reactions were carried out in a $15 \mu \mathrm{L}$ reaction volume with final concentrations of: $0.2 \mu \mathrm{M}$ forward and reverse primer, $0.2 \mu \mathrm{M}$ dNTPs, 1X PCR buffer, $3 \mu \mathrm{M} \mathrm{MgCl2}$, $0.5 \mathrm{U}$ Silverstar DNA polymerase (Eurogentec, Seraing, Belgium) and $3 \mu \mathrm{L}$ of extracted DNA. The PCR parameters were set as follows: initial denaturation at $94{ }^{\circ} \mathrm{C}$ for $5 \mathrm{~min}$, followed by 30 cycles of $94{ }^{\circ} \mathrm{C}$ for $1 \mathrm{~min}, 58^{\circ} \mathrm{C}$ for $1 \mathrm{~min}$ and $72{ }^{\circ} \mathrm{C}$ for $1 \mathrm{~min}$ with a final extension at $72{ }^{\circ} \mathrm{C}$ for $10 \mathrm{~min}$. 
Table II. Comparative test of the two detection methods (non specific amplification and SSCP vs. specific amplifications and CAPS) on 274 samples.

\begin{tabular}{|c|c|c|c|c|c|c|c|}
\hline $\begin{array}{l}\text { SA-CAPS } \\
\text { SSCP }\end{array}$ & E. alphitoides & E. quercicola & E. hypophylla & P. guttata. & $\begin{array}{l}\text { E. alphtoides } \\
+ \text { E. quercicola }\end{array}$ & $\begin{array}{c}\text { E.alphitoides } \\
+ \text { E. hypophylla }\end{array}$ & $\begin{array}{c}\text { TOTAL } \\
\text { SSCP }\end{array}$ \\
\hline E. alphitoides & 239 & 0 & 1 & 0 & 2 & 13 & 255 \\
\hline E. quercicola & 0 & 13 & 0 & 0 & 0 & 0 & 13 \\
\hline E.alphitoides + E. quercicola & 0 & 0 & 0 & 0 & 3 & 0 & 3 \\
\hline No detection & 0 & 0 & 0 & 1 & 0 & 2 & 3 \\
\hline TOTAL SA-CAPS & 239 & 13 & 1 & 1 & 5 & 15 & 274 \\
\hline
\end{tabular}

To further discriminate the two ITS types associated with $E$. alphitoides and E. quercicola, the cleaved amplified polymorphism (CAPS) technique was used. DNA amplification with ITS-ery F/ITSery $\mathrm{R}$ was followed by an enzymatic digestion of the PCR products using the PvuII enzyme. The amplified ITS sequence associated with E. alphitoides has a restriction site present at the position of the 377 th nucleotide which is not present in E. quercicola ITS sequence. E. alphitoides ITS sequence is therefore expected to give two fragments of $165 \mathrm{bp}$ and $377 \mathrm{bp}$ after digestion with PvuII whereas the sequence of E. quercicola is expected to show the original $542 \mathrm{bp}$ fragment after digestion. Two microlitres of each PCR product was digested in a $10 \mu \mathrm{L}$ reaction containing $1 \mathrm{U}$ of $P v u I I$. To rule out the possibility of partial digestions, PCR products were digested over night. Digested PCR products were electrophoresed on 1.2\% TBE agarose gels. The gels were stained with ethidium bromide, visualized, and photographed under UV light.

\subsection{Validation of the methods}

The validity of SSCP to discriminate the ITS types was checked with DNA templates from sequenced samples (Mougou et al., 2008). We verified that each type could indeed be differentiated by a specific band (data not shown). Similarly, to test the specificity of the specific designed primers for their corresponding species, each primer pair was used in a PCR reaction containing DNA template (already sequenced) encoding each ITS type. This test was performed on 15 DNA samples: four assigned to E. quercicola, three assigned to $P$. guttata, one assigned to E. hypophylla (since only one was available for this species) and seven assigned to E. alphitoides. The 15 DNA samples were amplified separately with the three different primer pairs. A lack of a PCR product after 30 cycles (using the corresponding PCR program) was deemed to demonstrate lack of crossreactivity between primers specific of a given ITS type and DNA from other ITS types. The PCR parameters were set as follows: initial denaturation at $94{ }^{\circ} \mathrm{C}$ for $5 \mathrm{~min}$, followed by 30 cycles of $94{ }^{\circ} \mathrm{C}$ for $1 \mathrm{~min}, 58^{\circ} \mathrm{C}$ for $1 \mathrm{~min}$ and $72{ }^{\circ} \mathrm{C}$ for $1 \mathrm{~min}$ with a final extension at $72{ }^{\circ} \mathrm{C}$ for $10 \mathrm{~min}$ for the two designed primer sets. PCR products were scored for successful amplification on $1 \%$ agarose gels. On the 15 DNA samples, the primer pairs ITS-ery F/ITS-ery R, ITS-hyp $\mathrm{F} / \mathrm{ITS}$-ery $\mathrm{R}$ and $\mathrm{PG}_{1} / \mathrm{PG}_{2}$ successfully amplified the target species and failed to amplify the non target ones. The DNA reference samples were also used to check that ITS sequences associated with E. alphitoides and E. quercicola showed two fragments of 165 and 377 bp and the original $542 \mathrm{bp}$ fragment respectively after digestion with PvuII.

Finally, the SSCP and the specific amplifications-CAPS (SACAPS) methods were compared on 274 samples from the three samplings (28 samples from Campet, 208 from the Pyrenean transect and
38 from the French regions), i.e. all 274 samples were analysed both in SSCP and with the three primer pairs and CAPS.

\section{RESULTS}

\subsection{Comparison of the SSCP and specific amplification-CAPS methods}

Very similar results were obtained by the two methods for E. alphitoides and E. quercicola: among the 258 positive samples for E. alphitoides in SSCP (255 alone and 3 with E. quercicola), 257 were also positive for E. alphitoides with SACAPS (Tab. II). Similarly, the 16 positive samples in SSCP for E. quercicola (13 alone and 3 with E. alphitoides) were also positive with SA-CAPS. SA-CAPS further allowed the detection of E. hypophylla (confirmed by sequencing) and P. guttata in some samples, especially E. hypophylla in addition to E. alphitoides in 13 samples where only E. alphitoides had previously been detected in SSCP.

\subsection{Detection success in the field samplings}

The overall success of detection was estimated by the number of lesions from which ITS was successfully amplified and characterized, over the total number of lesions. A high rate was obtained for the altitudinal gradient, 88.4\% (206/233) with SSCP, slightly increased when adding SA-CAPS (208/233). Much lower rates were obtained for the other two samplings: $50 \%$ (48/96) for Campet with SA-CAPS and 35.3\% (166/470) for the regional sampling with SSCP. For the latter, we observed a decreasing trend of amplification success over time with values of $43 \%, 36 \%, 28 \%$ and $16 \%$ for samples collected in June, July, August and September-October, respectively.

\subsection{Regional diversity}

E. alphitoides was the most frequently detected ITS type present in more than $80 \%$ lesions (Tab. III). ITS types corresponding to E. quercicola and E. hypophylla were also detected at low frequency ( $15 \%$ and $2 \%$, respectively). Only one ITS type was detected from a single lesion. Out of the 16 lesions located on the lower side of leaves, a PCR amplification was obtained for only nine and only the ITS type corresponding to E. alphitoides was detected. 
Table III. Detection of the different putative species (ITS types) for the three spatial levels of the study (in \% of samples were ITS types could be detected).

\begin{tabular}{|c|c|c|c|c|c|c|c|}
\hline & $\begin{array}{l}\text { Total number } \\
\text { of samples }\end{array}$ & $\begin{array}{l}\text { Number of samples } \\
\text { with positive detection }\end{array}$ & $\begin{array}{c}\text { E. alphitoides } \\
(\%)\end{array}$ & $\begin{array}{c}\text { E. quercicola } \\
(\%)\end{array}$ & $\begin{array}{c}\text { E. hypophylla } \\
(\%)\end{array}$ & $\begin{array}{c}\text { P. guttata } \\
(\%)\end{array}$ & $\begin{array}{c}\text { Multiple detections } \\
(\%)\end{array}$ \\
\hline Regional sampling & 470 & 166 & 82.5 & 15.1 & 2.4 & 0 & 0 \\
\hline Altitudinal gradient & 233 & 208 & 97.1 & 2.4 & 3.8 & 0 & 3.4 \\
\hline Campet forest & 96 & 48 & 85.4 & 20.8 & 8.3 & 12.5 & 27.1 \\
\hline
\end{tabular}

The total in each row can exceed $100 \%$ due to multiple detections, i.e. when two ITS types are detected in the same sample. For the regional and altitudinal samplings, data for E. alphitoides and E. quercicola were first obtained with SSCP; all samples were then amplified with specific primers of P. guttata and E. hypophylla. For the Campet sampling, the results are those of specific PCR-CAPS performed to detect the four ITS types. The PCR detection of the E. hypophylla ITS type was confirmed by sequencing.

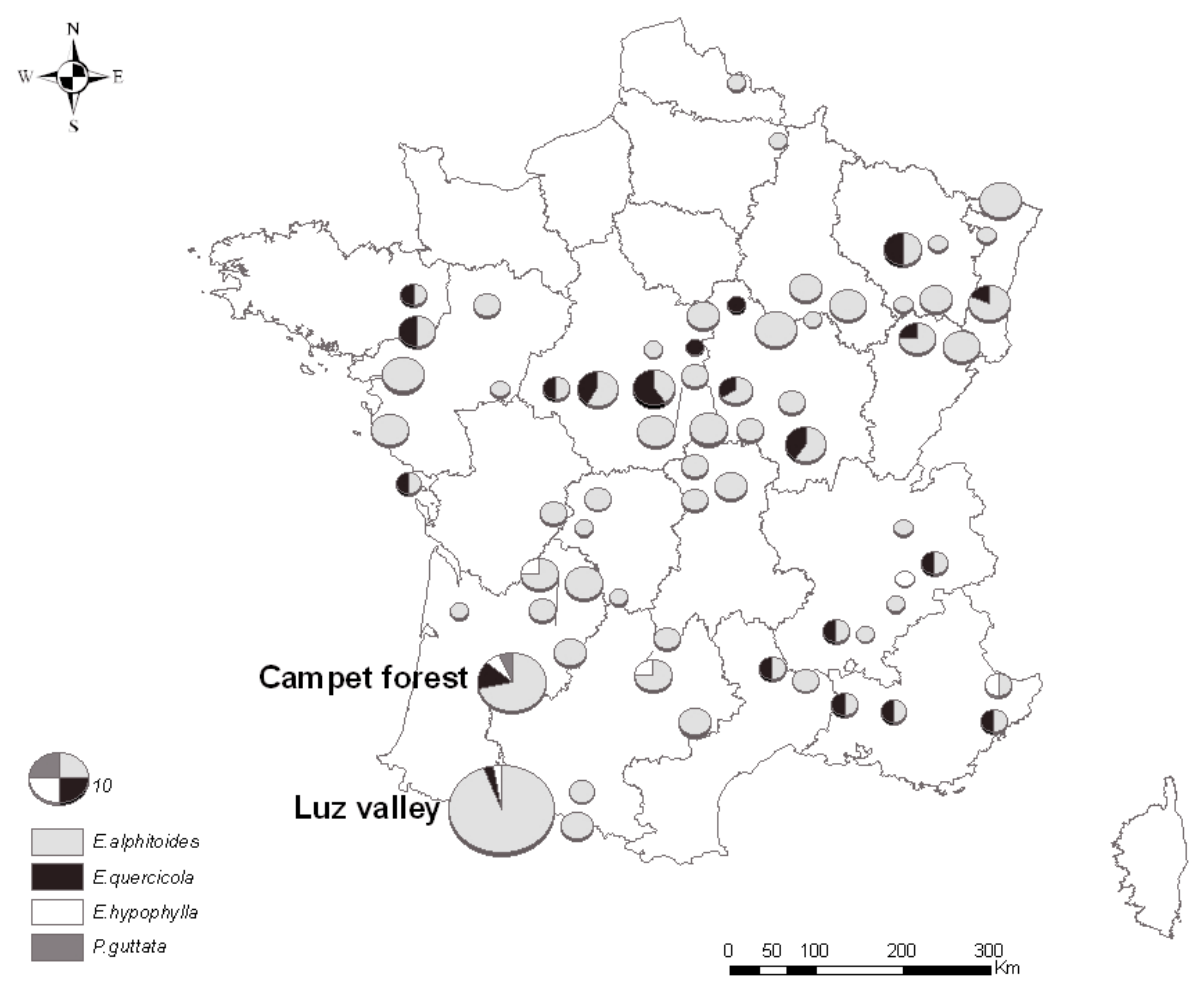

Figure 2. Distribution of the oak powdery mildew ITS types in France (regional DSF survey 2007, altitudinal sampling in Luz valley $2006-2007$ (208 samples) and local sampling in Campet Forest 2006 (48 samples); see text for details).

The geographical distribution of taxa showed that E. alphitoides ITS type was ubiquitous. The ITS type corresponding to E. quercicola was also found in almost all French regions. On the other hand, ITS corresponding to E. hypophylla was only found in southern regions, but in only seven stands (Fig. 2).

\subsection{Diversity across an altitudinal gradient}

The Pyrenean region showed a low diversity in ITS types: $97.1 \%$ (202 out of 208 samples) of lesions yielded the type related to E. alphitoides (Tab. III). ITS types related to E. quercicola and E. hypophylla were also present but at much lower frequencies, 2.4 and $3.8 \%$, respectively. In spite of these low frequencies, the two types were detected at almost all the altitudes from 400 to $1200 \mathrm{~m}$ for E. hypophylla and 400 to $1600 \mathrm{~m}$ for E. quercicola (Fig. 3). The E. hypophylla type was almost always detected in conjonction with that of E. alphitoides. All the E. hypophylla ITS types were detected in lesions collected in 2007, whereas the E. quercicola ITS type were equally detected in the two annual samplings (three in 2006 and two in 2007).

\subsection{Intra plot diversity: Campet Forest}

E. alphitoides was detected from most samples in the Campet forest (85\% of lesions) in all but one sampled trees (Tab. III, Fig. 4). Nine out of the 17 oak trees were also positive for E. quercicola ITS type. E. hypophylla and P. guttata ITS types were rarer. Three different ITS types were found on four trees i.e. trees 3, 5, 7 and 11 (Fig. 4). 


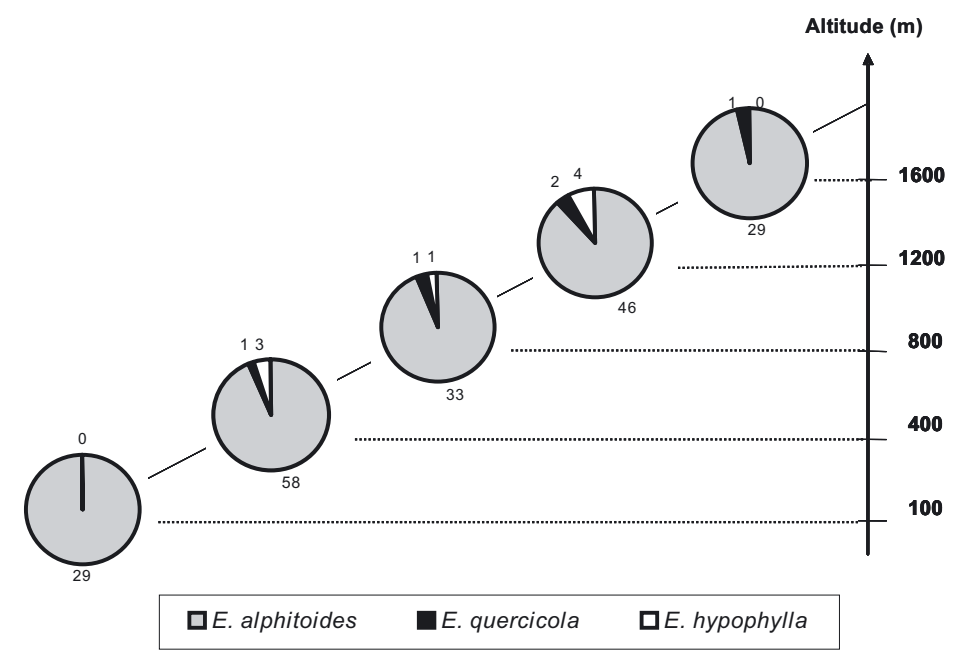

Figure 3. Distribution of the Erysiphe ITS types across the Pyrenean gradient (2006 and 2007 samplings). E. hypophylla ITS type was mostly detected in conjunction with E. alphitoides.

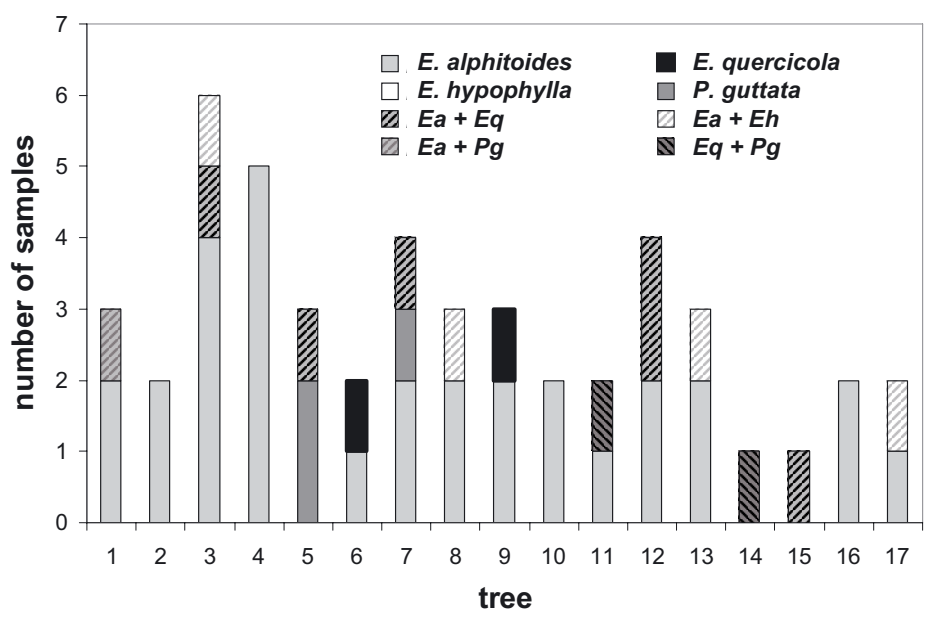

Figure 4. Distribution of the different ITS types in oak trees in Campet (all trees are $Q$. robur except \#16 which is $Q$. pyrenaica). Stripes indicate multiple detections.

A significant effect of the leaf side on the distribution of ITS types was found. The E. quercicola ITS type was relatively more frequent when lesions were sampled on the lower side than on the upper side of leaves ( 7 samples vs. 3, respectively), contrary to the E. alphitoides (11 vs. 30), E. hypophylla (0 vs. 4$)$ and $P$. guttata (1 vs. 5) types which were more frequent on the upper side (Chi-2 $=14.72, \mathrm{~d} f=3, P=0.002)$.

At lesion level, a relatively high proportion of mixed infections (27\%), i.e. when more than one ITS type was detected, was found (Tab. III). Actually, the E. hypophylla ITS type was only found in association with the E. alphitoides ITS type. E. quercicola and $P$. guttata ITS types were also mostly found in mixtures (results not shown).

\subsection{Host specificity}

The distribution of powdery mildew ITS types over the different oak species was analyzed only in the regional sampling, since sampling performed on the altitudinal gradient and in the Campet forest targeted $Q$. robur. The E. alphitoides ITS type was detected on the five oak species sampled (Tab. IV). $E$. quercicola and E. hypophylla ITS types were also found on several host species. A differential association between the oak species and the ITS types was tested for $Q$. robur, $Q$. pubescens and $Q$. petraea/E. alphitoides and E. quercicola, for which enough data were available. No such association could be found $(\mathrm{Chi}-2=1.33, \mathrm{~d} f=2, P=0.68)$.

\section{DISCUSSION}

A strong limitation in the study of powdery mildew lies in the biotrophic lifestyle of these fungi, which cannot be cultured on artificial media. The use of molecular tools has greatly improved our knowledge in recent years, in particular on oak powdery mildew (Mougou et al., 2008; Takamatsu 
Table IV. Distribution of powdery mildew species ITS (number of samples) across oak species in the French regions sampling.

\begin{tabular}{|c|c|c|c|c|c|c|c|}
\hline & Q. robur & Q. pubescens & Q. petraea & Q. pyrenaica & Q. cerris & Unidentified Quercus sp. & Total \\
\hline E. alphitoides & 69 & 10 & 26 & 2 & 1 & 29 & 137 \\
\hline E. quercicola & 13 & 4 & 6 & 0 & 0 & 2 & 25 \\
\hline E. hypophylla & 2 & 1 & 0 & 0 & 0 & 1 & 4 \\
\hline
\end{tabular}

et al., 2007). However, so far, only a limited number of samples had been examined. A first achievement of the present study was the development of quick molecular detection methods that can be applied on large samplings, especially for the two most frequent ITS types associated with E. alphitoides and E. quercicola, respectively.

A very high detection yield was only achieved in the altidudinal gradient sampling, with fresh, highly sporulating lesions, directly processed in the laboratory less than $20 \mathrm{~d}$ after infection and incubation under favourable conditions. Conversely, older lesions (in the sampling from the Campet forest) or desiccated samples (powdery mildew lesions sent by DSF technicians from different French regions) showed a lower success of detection suggesting DNA degradation or production of secondary metabolites limiting PCR amplification. The decreasing trend of amplification success from June to October in the regional sampling might also reflect a decreasing activity of the fungus resulting in lower DNA yields. Obtaining a high good-quality DNA yield has been reported to be problematic in Ascomycota fungi, and is even more critical in the biotrophic Erysiphales where small amounts of fungal material are available (Cunnington et al., 2003; Dutech et al., 2007). Our results strongly suggest that the success of amplification for oak powdery mildew from natural lesions is dependent on the lesion stage.

The SSCP method developed in this study proved to be a convenient method to detect the ITS sequences associated with E. alphitoides and E. quercicola. SSCP results for E. alphitoides and E. quercicola were highly consistent with those obtained by specific detection-CAPS. Previous studies had already shown that PCR-SSCP is a reliable tool for the taxonomy and identification of pathogenic fungi within a genus (Kong et al., 2003; Sunnucks et al., 2000). In contrast, we were unable to detect the rarer ITS of $P$. guttata and E. hypophylla by the SSCP method. Such SSCP detection failure might be explained by a dominance bias, since these ITS were mostly detected in association with E. alphitoides by using specific primers. PCR products for SSCP are amplified with non specific primers, therefore the most abundant ITS sequence is more likely to be amplified in mixtures, leading to an underestimation of non dominant ITS sequences. A further difficulty in the detection of E. hypophylla was a lack of specificity of the designed primers, in spite of the results obtained in the validation study (but with only one reference DNA). For the whole sampling study, $38 \%$ of positive amplifications with ITS hypF/ITS eryR yielded $E$. alphitoides ITS sequences, i.e. were probably false positives (results not shown). The situation of E. hypophylla will require clarification in many aspects. Its taxonomic position, especially whether it is conspecific to E. alphitoides or a distinct species, is still debated.
Based on morphological features, some authors considered E. hypophylla as a synonym of E. alphitoides and others as a distinct species (Braun, 1995). Some ITS sequences obtained from samples isolated on Paeonia lutea and described as E. hypophylla corresponded to E. alphitoides ITS sequence (Takamatsu et al., 2006). Sequences of additional genes and multigene phylogeny analyses could be useful to investigate the status of these species

The main contribution of the current study was the confirmation on a large sampling of the occurrence in France of four ITS sequences corresponding to different species described as causal agents of oak powdery mildew (Mougou et al., 2008).

The ITS type associated with E. alphitoides was the most represented with a frequency higher than $80 \%$ in the three levels of the study (Campet, Pyrenees and French regions). Erysiphe alphitoides has been considered as the main if not sole causal agent of powdery mildew since the apparition of this disease on oak (Viennot-Bourgin, 1949). This species is currently present in all the French regions.

A major finding was the detection of the ITS sequence associated with E. quercicola in almost all the French regions. The frequency (15\%) observed in the regional sampling is consistent with that obtained during a first survey in France (Mougou et al., 2008). The lower occurrence of E. quercicola ITS as compared to E. alphitoides could be due to a more recent introduction of this species in Europe. However, its large geographic distribution does not support this hypothesis. An alternative hypothesis to explain the predominance of isolates of $E$. alphitoides type over E. quercicola type is that some climatic requirements might favour the earlier arrival of E. alphitoides onto the host; this earlier setting up giving the fungus a competitive advantage. The advantage from earlier arrival onto a host has already been suggested for the two wheat pathogenic fungi Puccinia triticina and Pyrenophora triticirepentis (Al-Naimi et al., 2005). Temporal succession has also been described for the two genetic groups of Erysiphe necator (Montarry et al., 2009). Such hypothesis requires to be tested for oak powdery mildew with an appropriate temporal sampling. In the present study, there was no indication of a time effect on the relative detection of the E. alphitoides and E. quercicola ITS types in the regional sampling, but the low number of later samples precluded any conclusion (results not shown). It has to be noticed that a rather low frequency of $E$. quercicola ITS type was detected in the Pyrenees, where sampling was rather early, compared to the country-level frequency. However, the difference in host status (seedlings versus adult trees) and climatic conditions cannot be discarded to explain these differences.

The ITS sequence associated with E. hypophylla was detected (and confirmed by sequencing) in 2 to $8 \%$ of the 
sampled powdery mildew lesions. Up to now, records of this species, based on morphology, were mainly from Eastern and Northern Europe (Roll-Hansen, 1961) and Viennot-Bourgin (1968) hypothesized a westward expansion. Conversely, we found the E. hypophylla ITS type only in the South of France, from East to the Atlantic coast. Another unexpected result was the association of E. hypophylla ITS with lesions on the upper side of leaves. However, this finding could be an artefact, due to the joint occurrence of E. alphitoides in all samples where E. hypophylla was detected. In these cases, the visible sporulating lesion, on the upper side, was probably caused by $E$. alphitoides, while E. hypophylla could be present in an inconspicuous lesion on the lower side of the leaves. As mentioned before, results about this species are to be taken with caution until appropriate genetic markers can allow better identification and detection.

Finally, an ITS sequence corresponding to $P$. guttata (sensu lato) was detected at a low frequency $(<15 \%)$. P. guttata has been reported from many species, especially Corylus and Fraxinus but also Quercus in Europe, with some authors referring to the latter as $P$. roboris (Viennot-Bourgin, 1949). $P$. guttata actually corresponds to a complex of cryptic species, as recently shown by Takamatsu et al. (2008). The different species which can infect Quercus need to be further characterized. The primer sequences used in our study are probably not adequate to detect them all. Indeed, the PG1 primer sequence does not match the sequence described for $P$. roboris from Castanea in Takamatsu et al. (2008). A second Phyllactinia complex of cryptic species causing oak powdery mildew, besides the Erysiphe complex, cannot therefore be ruled out. Another limitation of our method when dealing with Phyllactinia species relies in the DNA extraction without leaf grinding. Since Phyllactinia, contrary to Erysiphe, have a semi endophytic habit (Viennot-Bourgin, 1949), this may lead to a reduced detection and therefore an underestimation of their occurrence. The more frequent detection of Phyllactinia in samples with visible lesions on the upper-leaf-side was unexpected since Phyllactinia are usually described as mainly sporulating on the lower side of leaves (Viennot-Bourgin, 1949). The explanation presented for E. hypophylla may also hold for P. guttata.

A striking result of the study was the co-occurrence of several species (or at least ITS) at all spatial scales considered. The only suggestion of a spatial differentiation was a higher relative occurrence of $E$. quercicola ITS types in samples taken from the lower side of leaves as compared to E. alphitoides. Ultraviolet-B was shown to influence the abundance and distribution of $E$. alphitoides on $Q$. robur (Newsham et al., 1997; 2000). It would be interesting to test experimentally a differential effect of UV radiations on the four species which might explain an association between the leaf side and the prevalence of species. The coexistence of various ITS types was shown not only on the same tree but even in the same lesion. Mixed lesions were the most frequent in the Campet sampling which might be explained by a slightly larger size of samples or by an older stage of development of the disease. Whereas sampled lesions in the altitudinal study might be hypothesized to result mostly from single infection events, older lesions, such as those sampled in Campet, might correspond to the coalescence of several colonies.

The maintenance of polymorphism in natural populations, either between species or between genotypes, such as in multiple infections, is an important question in ecology, suggesting the existence of mechanisms balancing competitive exclusion (Brose, 2008). Parasite mediation has been considered as a factor altering direct competition between species (Price et al., 1986). Powdery mildew fungi, including E. alphitoides, are parasitized by Ampelomyces quisqualis Ces. (synonym Cicinnobolus cesatii) (Kiss, 1998). The potential role of this or other fungal antagonists in maintaining a diversity of oak powdery mildew fungi in relation to differential host specificity remains to be investigated.

In conclusion, this study mainly raises the question of the occurrence of E. quercicola in France. Although samples having an ITS sequence matching that of E. quercicola were found throughout the country, the formal identification of this species in France remains to be done, based on morphological features and additional genetic data. If confirmed, the origin of this species, its biological, including pathogenicity features, especially as compared to E. alphitoides, will need further investigation.

Acknowledgements: The authors sincerely thank officers and technicians of the Département Santé des Forêts, French Ministry of Agriculture, for the country-wide sampling, and Xavier Capdevielle for help in the Pyrenean and Campet samplings. Financial support was obtained from the French ANR (Agence Nationale de la Recherche), in the DRYADE project. We are very grateful to Corinne Vacher, François Delmotte, Nicolas Feau and two anonymous reviewers for helpful comments on a previous version of this manuscript.

\section{REFERENCES}

Al-Naimi F.A., Garett K.A., and Bockus W.W., 2005. Competition, facilitation, and niche differentiation in two foliar pathogens. Oecologia 143: 449-457.

Ayres P.G., 1976. Natural resistance to oak mildew. Arboric. J. 3: 23-29.

Benbouza H., Jacquemin J.-M., Baudoin J.-P., and Mergeai G., 2006. Optimization of a reliable, fast, cheap and sensitive silver staining method to detect SSR markers in polyacrylamide gels. Biotechnol. Agron. Soc. Environ. 10: 77-81.

Braun U., 1995. The powdery mildews (Erysiphales) of Europe. Gustav Fischer Verlag, Stuttgart, New York.

Brose U., 2008. Complex food webs prevent competitive exclusion among producer species. Proc. R. Soc. B. 275(1650): 2507-2514.

Butin H. H., 1995. Tree diseases and disorders: causes, biology, and control in forest and amenity trees, Oxford University Press, Oxford, $252 \mathrm{p}$.

Crous P.W., Groenewald J.Z., Pongpanich K., Himaman W., Arzanlou M., and Wingfield M.J., 2004. Cryptic speciation and host specificity among Mycosphaerella spp. occurring on Australian Acacia species grown as exotics in the tropics. Studies Mycol. 50 Special Issue, Part 2: $457-469$.

Cunnington J.H., Takamatsu S., Lawrie A.C., and Pascoe I.G., 2003. Molecular identification of anamorphic powdery mildews (Erysiphales). Aust. Plant Pathol. 32: 421-428. 
Delye C. and Corio-Costet M.-F., 1998. Origin of primary infections of grape by Uncinula necator. RAPD analysis discriminates two biotypes. Mycol. Res. 102: 283-288.

Dutech C., Enjalbert J., Fournier E., Delmotte F., Barrès B., Carlier J., Tharreau D., and Giraud T., 2007. Challenges of microsatellite isolation in fungi. Fungal. Genet. Biol. 44: 933-949.

Edwards M.C. and Ayres P.G., 1982. Seasonal changes in resistance of Quercus petraea (sessile oak) leaves to Microsphaera alphitoides. Trans. Br. Mycol. Soc. 78: 569-571.

Fournier E. and Giraud T., 2008. Sympatric genetic differentiation of a generalist pathogenic fungus, Botrytis cinerea, on two different host plants, grapevine and bramble. J. Evol. Biol. 21: 122-132.

Griffon E. and Maublanc A., 1912. Les Microsphaera des chênes. Bull. Soc. Mycol. F. 28: 88-104.

Hebert P.D.N., Cywinska A., Ball S.L., and deWaard J.R., 2003. Biological identifications through DNA barcodes. Proc. R. Soc. Lond., B, Biol. Sci. 270: 313-321.

Heuser T. and Zimmer W., 2002. Quantitative analysis of phytopathogenic ascomycota on leaves of pedunculate oaks (Quercus robur L.) by real-time PCR. FEMS Microbiol. Lett. 209: 295-299.

Kiss L., 1998. Natural occurrence of Ampelomyces mycoparasites in mycelia of powdery mildew fungi. New Phytol. 140: 709-714.

Kong P., Hong C., Richardson P.A., and Gallegly M.E., 2003. Singlestrand-conformation polymorphism of ribosomal DNA for rapid species differentiation in genus Phytophthora. Fungal. Genet. Biol. 39: $238-249$.

Limkaisang S., Kom-un S., Luiz Furtado E., Liew W.K., Salleh B., Sato Y., and Takamatsu S., 2005. Molecular phylogenetic and morphological analyses of Ö̈dium heveae, a powdery mildew of rubber tree. Mycoscience 46: 220-226.

Limkaisang S., Cunnington J.H., Liew K.W., Salleh B., Sato Y., Divarangkoon R., Fangfuk W., To-anun C., and Takamatsu S., 2006. Molecular phylogenetic analyses reveal a close relationship between powdery mildew fungi on some tropical trees and Erysiphe alphitoides, an oak powdery mildew. Mycoscience 47: 327-335.

Lowe T., Shareifkin J., Yang S.Q., and Dieffenbach C.W., 1990. A computer program for selection of oligonucleotide primers for polymerase chain reaction. Nucleic Acids Res. 18: 1757-1761.

Mmbaga M.T., Klopfenstein N.B., Kim M.-S., and Mmbaga N.C., 2004. PCR-based identification of Erysiphe pulchra and Phyllactinia guttata from Cornus florida using ITS-specific primers. Eur. J. For. Pathol. 34: 321-328.

Montarry J., Cartolaro P., Delmotte F., Jolivet J., and Willocquet L., 2008. Genetic structure and aggressiveness of Erysiphe necator populations during grapevine powdery mildew epidemics, Appl. Environ. Microbiol. 74: 6327-6332.

Montarry J., Cartolaro P., Richard-Cervera S., and Delmotte F., 2009. Spatio-temporal distribution of Erysiphe necator genetic groups and their relationship with disease levels in vineyards. Eur. J. Plant Pathol. 123: 61-70.

Mougou A., Dutech C., and Desprez-Loustau M.-L., 2008. New insights into the identity and origin of the causal agent of oak powdery mildew in Europe. For. Pathol. 38: 275-287.

Newsham K.K., Low M.N.R., Mcleod A.R., Greenslade P.D., and Emmett B.A., 1997. Ultraviolet-B radiation influences the abundance and distribution of phylloplane fungi on pedunculate oak (Quercus robur). New Phytol. 136: 287-297.
Newsham K.K., Oxborough K., White R., Greenslade P.D., and Mcleod A.R., 2000. UV-B radiation constrains the photosynthesis of Quercus robur through impacts on the abundance of Microsphaera alphitoides. For. Pathol. 30: 265-275.

Nilsson R.H., Kristiansson E., Ryberg M., Hallenberg N., and Larsson K.H., 2008. Intraspecific ITS variability in the Kingdom Fungi as expressed in the International Sequence Databases and its implications for molecular species identification. Evol. Bioinf. 4: 193-201.

Orita M., Iwahana H., Kanazawa H., Hayashi K., and Sekiya T., 1989. Detection of Polymorphisms of Human DNA by Gel Electrophoresis as SSCPs. Proc. Natl. Acad. Sci. USA 86: 2766-70.

Price P.W., Westoby M., Rice B., Atsatt P.R., Fritz R.S., Thompson J.N., and Mobley K., 1986. Parasite mediation in ecological interactions. Ann. Rev. Ecol. System. 17: 487-505.

Roll-Hansen F., 1961. Microsphaera hypophylla Nevodovskij (M. silvatica Vlasov), an oak powdery milfew fungus. Rep. Norw. For. Res. Inst. 17: 37-61.

Rozen S. and Skaletsky H.J., 2000. Primer3 on the WWW for general users and for biologist programmers. In: Krawetz S. and Misener S. (Eds.), Bioinformatics methods and protocols: Methods in molecular biology, Humana Press, Totowa, NJ, pp. 365-386.

Saenz G.S. and Taylor J.W., 1999. Phylogeny of the Erysiphales (powdery mildews) inferred from internal transcribed spacer ribosomal DNA sequences. Can. J. Bot. 77: 150-168.

Sunnucks P., Wilson A.C.C., Beheregaray L.B., Zenger K., French J., and

Taylor A.C., 2000. SSCP is not so difficult: the application and utility of single-stranded conformation polymorphism in evolutionary biology and molecular ecology. Mol. Ecol. 9: 1699-1710.

Takamatsu S., 2004. Phylogeny and evolution of the powdery mildew fungi (Erysiphales, Ascomycota) inferred from nuclear ribosomal DNA sequences. Mycoscience 45: 147-157.

Takamatsu S., Bolay A., Limkaisang S., Kom-un S., and To-anun C., 2006. Identity of a powdery mildew fungus occuring on Paeonia and its relationship with Erysiphe hypophylla on oak. Mycoscience 47: 367-373.

Takamatsu S., Braun U., Limkaisang S., Kom-un S., Sato Y., and Cunnington J.H., 2007. Phylogeny and taxonomy of the oak powdery mildew Erysiphe alphitoides sensu lato. Mycol. Res. 111: 809-826.

Takamatsu S., Inagaki M., Niinomi S., Khodaparast S.A., Shin H.-D., Grigaliunaite B., and Havrylenko M., 2008. Comprehensive molecular phylogenetic analysis and evolution of the genus Phyllactinia (Ascomycota: Erysiphales) and its allied genera. Mycol. Res. 112: 299-315.

Taylor J.W., Turner E., Townsend J.P., Dettman J.R., and Jacobson D., 2006. Eukaryotic microbes, species recognition and the geographic limits of species: examples from the kingdom Fungi. Philo. Trans. R. Soc. Lond., B, Biol. Sci. 361: 1947-1963.

Viennot-Bourgin G., 1949. Les champignons parasites des plantes cultivées, Masson, Paris, 755 p.

Viennot-Bourgin G., 1968. Note sur les Erysiphacées. Bull. Soc. Mycol. Fr. 84: 117-118.

White T.J., Bruns T., Lee S., and Taylor J., 1990. Genetics and evolution in amplification and direct sequencing of fungal ribosomal RNA genes for phylogenies. In: Innis M., Gelfand D., Sninsky J., and White T. (Eds.), PCR protocols: a guide to methods and applications, Academic Press, Orlando, pp. 315-322.

Zolan M.E. and Pukkila P.J., 1986. Inheritance of DNA methylation in Coprinus cinereus. Mol. Cell. Biol. 6: 195-200. 